\title{
ОСОБЕННОСТИ БАНКРОТСТВА ИНДИВИДУАЛЬНОГО ПРЕДПРИНИМАТЕЛЯ
}

\section{FEATURES OF BANKRUPTCY OF AN INDIVIDUAL ENTREPRENEUR}

\section{A. Gudkov \\ A. Krasilschikov \\ V. Mishchenko}

Summary. The article analyzed the conditions for the onset of bankruptcy of individual entrepreneurs, the procedural procedure for exercising the rights of creditors, and also reveals some of the problems of bankruptcy in practice: the timing of the consideration of the case, the debtor's affiliation, assignment of claims and other features of the procedure. It also touches upon important aspects of invalidating suspicious transactions of the debtor, taking into account the period of claim.

Keywords: bankruptcy, insolvency, circle of creditors, individual entrepreneur, debt mass, persistent insolvency, bankruptcy commissioner.

Б анкротство физического лица индивидуального предпринимателя (ИП) - один из популярных способов погасить долги, которые невозможно выплатить, в том числе, если недостаточно имущества. Согласно данным Росстата за 2019 год, по состоянию на 30.06.2019 в судах рассматривалось около 100 тысяч дел о банкротстве [5]. Только за первое полугодие 2019 года судами было принято более 61 тысячи заявлений о возбуждении банкротства индивидуальных предпринимателей [5].

Как правило, банкротство возникает, если предприниматель осознает, что накопил долги перед бюджетом и не в силах их погасить, либо не может длительное время рассчитаться по долгам с контрагентом, либо задолжал кредиторам, не имея впереди финансовых перспектив. В процессе банкротства физлица к делу могут присоединиться другие кредиторы, перед которыми задолжал должник. Возбуждение банкротства производится через арбитражный суд по месту регистрации и фактического проживания предпринимателя.

Для банкротства индивидуального предпринимателя необходимо соответствовать определенным параметрам: иметь стойкую неплатежеспособность. Например, ИП не может вернуть долг, заем, покрыть убытки, выпла-
Гудков Анатолий Иванович

К.ю.н., дочент, ВЮИ ФСИН России

gudkovaniv@yandex.ru

Красильщиков Анатолий Владимирович

К.ю.н., дочент, ВЮИ ФСИН России

krasilschikov@inbox.ru

Мищенко Вячеслав Иванович

К.ф.н., дочент, ВЮИ ФСИН России

vyacheslav-mischenko@mail.ru

Аннотация. В статье анализируются условия наступления банкротства индивидуальных предпринимателей, процессуальный порядок реализации прав кредиторов, а также раскрываются некоторые проблемы банкротства на практике: сроки рассмотрения дела, аффилированность должника, уступка требований и иные особенности процедуры. Также затрагиваются важные аспекты признания подозрительных сделок должника недействительными с учетом искового срока.

Ключевые слова: банкротство, несостоятельность, круг кредиторов, индивидуальный предприниматель, долговая масса, стойкая неплатежеспособность, арбитражный управляющий.

тить зарплату, оплатить налоги и финансовые обязательства перед контрагентами. В процессе банкротства ИП не может брать кредиты, займы или удовлетворять интересы отдельных кредиторов в ущерб другим.

Провести добровольное банкротство можно по инициативе предпринимателя или его должника. Объявление о банкротстве ИП - важный и главный этап, свидетельствующий о начале процедуры банкротства. Основанием для начала банкротства является определение арбитражного суда о возбуждении дела о банкротстве ИП, в рамках которого предприниматель признается неплатежеспособным и назначается финансовый управляющий, в ведение которого переходят функции распорядителя имущества.

Следующим этапом определяется круг кредиторов, заинтересованных в погашении долгов за счет реализации имущества должника ИП. Случается, что кредиторами хотят стать лица, претензии которых не обоснованы или просрочены. Требования по процедуре банкротства прописаны в законе, и потому каждый кредитор заинтересован в его соблюдении. В этом случае арбитражный управляющий или иные кредиторы вправе обжаловать признание судом лица кредитором по статье 61.9 Федерального закона 
№ 127-Ф3 о несостоятельности (банкротстве) [1]. При этом Верховный Суд РФ разъяснил в Определении от 04.03.2021 года по делу № 305-ЭС17-2507(21), что срок обжалования подозрительных сделок ограничен трехлетним периодом, предшествующим дню возбуждения дела о банкротстве [4].

Известно, что вместе с долгами, как правило, растут пени и штрафы, предусмотренные договором, в итоге начальный долг может увеличиться в несколько раз и разорить ИП. Если оценить экономическую ситуацию реально, то при стечении негативных обстоятельств и отсутствии возможности погасить долг в течение длительного периода, единственно правильным решением ИП, на наш взгляд, будет решение об официальном объявлении себя банкротом в судебном порядке. В период банкротства, с момента возбуждения дела в суде, у предпринимателя прекращается обязанность по выплате налогов и штрафов, больше не начисляются пени и проценты, таким образом прекращают расти долги. Считается, что любая сумма долга, имеющаяся на день возбуждения дела о банкротстве в суде, «замораживается», а, значит, должник может остановить нарастающий ком долговых обязательств, что уже немаловажно.

Последствием банкротства индивидуального предпринимателя является его ликвидация и исключение из госреестра. Несмотря на то, что статус предпринимателя прекращается в процессе банкротства, через некоторое время гражданин может открыть новое ИП и переквалифицировать свою основную деятельность.

Несостоятельность (банкротство) имеет место быть при наличии определенных признаков: невозможность рассчитаться с долгами более трех месяцев подряд, наличие неисполненного долга в размере более 500 000 руб. на протяжении данного периода времени.

Процесс банкротства бывает добровольным, инициированным самим должником, либо запускается по инициативе кредитора. Процедура банкротства состоит из нескольких этапов и различна в зависимости от механизма ее запуска. При добровольном банкротстве необходимо пройти следующие этапы: принятие решения о банкротстве; объявления банкротом в судебном порядке и назначение управляющего банкротством, публикация объявления о банкротстве, формирование реестра кредиторов, погашение долгов за счет реализации имущества должника, прекращение [3].

При принудительном банкротстве по заявлению кредитора процесс состоит из таких этапов: возбуждение дела о банкротстве в Арбитражном суде и назначение судом управляющего по ходатайству кредитора; реструктуризация долгов; формирование реестра кредиторов; переуступка долга или кредиторского требования; подписание мирового соглашения между кредиторами и должником; определение порядка очередности погашения долгов; обжалование включения кредиторов, не имеющих права взыскания либо обратившихся в суд без достаточных оснований; проведение торгов и реализация конкурсного имущества; выплата долгов; исключение предпринимателя из государственного реестра [3].

Банкротство позволяет индивидуальному предпринимателю избавиться от долгового шлейфа и сохранить имущество, которое не может быть арестовано по закону, когда отсутствует процедура банкротства. Таким образом, предприниматель-банкрот может хотя бы сохранить единственное жилье для своей семьи и личные вещи. Важно отметить, что при реализации не все имущество может быть продано на торгах, так как закон позволяет должнику сохранить единственное жилье, в котором он постоянно проживает.

Многие банкротства предпринимателей являются следствием неисполненных кредитных обязательств перед банками или иными финансовыми учреждениями, предоставляющими заемные средства. Начисляемые проценты на тело кредита могут оказаться намного выше самого долга, если насчитывается неустойка за просрочку выполнения обязательства.

Поэтому банкротство индивидуального предпринимателя с долгами по кредитам - один из действенных способов прекратить увеличение долга и зафиксировать его размер. При этом в период банкротства проценты по кредитам и неустойка не начисляются, а кредитные обязательства «замораживаются». Важно, что при банкротстве ИП списываются долги, по которым не истек срок давности. При этом убытки банков покрываются как за счет реализованного имущества должника, так и за счет страховой премии, которая выплачивается страховой компанией, являющейся гарантом по кредиту.

Стоит перечислить основные моменты, благодаря которым банкротство выполняет ключевую роль в рефинансировании ИП. Во-первых, банкротство позволяет взять тайм-аут и «заморозить» долговую массу, демонстрируя перед кредиторами, что должник больше не может обещать, но готов расплатиться по счетам сейчас тем, что у него осталось. Во-вторых, важно, что часть имущества должника не может быть изъята в конкурсную массу. В частности, это касается имущества его супруга и детей, а также недвижимого имущества, которое является него единственным жильем, в том числе личных и профессиональных вещей. Кроме того, в банкротную массу не входит арендованное имущество и имущество детей, 
супруга. В статье 132 Закона о банкротстве содержится перечень такого имущества [1].

В-третьих, конкурсное производство позволяет оценить имущество должника и продать его на торгах по максимальной цене, удовлетворив все претензии кредиторов. При этом имущество, которое не будет востребовано, может вернуться во владение должника, если долги будут погашены, либо участники банкротства подпишут мировое соглашение.

В-четвертых, в период банкротства долговую массу ИП может приобрести третье лицо, не участвующее в банкротстве, или кредитор. Фактически может произойти процесс реструктуризация долгов, когда их выкуп производится через арбитражный суд платежеспособным инвестором.

Однако, следует учесть, что банкротство ИП имеет также и негативную сторону для должника или положительную для кредиторов. Например, в случае, если срок исковой давности не позволял заинтересованному кредитору обратиться с иском о признании сделки должника недействительной, то закон о банкротстве позволил оспорить любые сделки должника, предшествующие трехлетнему периоду обращения в суд. Таким образом, кредитор получил законное право, которого не было у него до возбуждения процедуры банкротства предпринимателя.

Незаконные действия или бездействие арбитражного управляющего могут быть обжалованы любыми участниками банкротства, включая самого должника. В частности, конкурсный кредитор вправе обратиться с иском в арбитражный суд, рассматривающий дело о банкротстве, с иском о признании сделки должника и одного из кредиторов недействительной, а также применить последствия недействительности сделки. Обоснованием может стать заключение подозрительной сделки должника в ущерб иным кредиторам. При этом под обжалования попадают все подозрительные сделки должника, заключенные за три года до дня возбуждения дела о его банкротстве. В результате реализации законных прав кредиторов в большинстве случаев дела о банкротстве рассматриваются от одного года до трех лет, хотя процессуальными нормами установлен предельный срок рассмотрения дел о банкротстве арбитражными судами. Согласно статье 51 АПК РФ срок рассмотрения данных дел - семь месяцев со дня возбуждения банкротства индивидуального предпринимателя. На практике указанная процессуальная норма не исполняется, что создает мнимые предположения для кредиторов для понимания сроков рассмотрения дел и удовлетворения их законных претензий. Фактически, возбуждая банкротство, кредитор рассчитывает на вынесение решения суда в пределах семимесячного срока, поэтому производит соответствующие затраты на адвокатов. Так как пеня и проценты за период банкротства не начисляется, то затяжное рассмотрение дел по банкротству ИП приводит к значительным убыткам конкурсных кредиторов.

Законом предусмотрено заключение мирового соглашения кредиторов

с должником на любой стадии арбитражного процесса. Вместе с тем данная норма практически не работает, так как предусматривает единство в принятии решения о заключении мирового соглашения всеми кредиторами. Зачастую заявителями становятся аффилированные с должником лица, которые не заинтересованы в заключении мирового соглашения, что соответственно делает невозможным его заключение на первых стадиях процесса.

В отличие от банкротства юридических лиц, процесс банкротства предпринимателей немного упрощен. В частности, закон о банкротстве предусматривает упрощенную процедуру банкротства в случае наличия стойкой задолженности в сумме не менее 50 тысяч рублей, В случае упрощенного производства также предусмотрен максимальный долговой порог в 500 тысяч рублей. Фактически ряд банкротных дел предпринимателей решаются на стадии исполнительных производств в ФССП, что значительно разгрузило суды. При этом с 2020 года в отношении банкротства индивидуальных предпринимателей в период пандемии коронавируса, в порядке исключения, апрельским Постановлением Правительства № 428 [2] введен мораторий, не позволяющий возбуждать банкротства, возникшие на фоне падения экономики в форс-мажорный для страны период. Исключением стали банкротные производства ИП, возбужденные в судах до введения моратория.

\section{ЛИТЕРАТУРА}

1. Федеральный закон «0 несостоятельности (банкротстве)» от 26.10.2002 N127-Ф3. // http://www.consultant.ru/document/cons_doc_LAW_39331.

2. Постановление Правительства РФ от 03.04.2020 г. № 428 «0 введении моратория на возбуждение дел о банкротстве по заявлению кредиторов в отношении отдельных должников». // http://publication.pravo.gov.ru/Document/View/0001202004060020

3. Постановление Пленума Высшего Арбитражного Суда Российской Федерации от 2.06 .2012 г. № 35 «0 некоторых процессуальных вопросах, связанных с рассмотрением дел о банкротстве».// http://base.garant.ru/70203722/ 
4. Обзор судебной практики разрешения споров, связанных сустановлением в процедурах банкротства требований контролирующих должника и аффилированных с ним лиц, утвержденный 29.01.2020 г. Президиумом ВС РФ.// http://www.consultant.ru/document/cons_doc_LAW_344078/

5. Адвокатская газета // https://www.advgazeta.ru/novosti/kolichestvo-zayavleniy-i-del-o-bankrotstve-grazhdan-neuklonno-rastet/

(ㄷ Гудков Анатолий Иванович ( gudkovaniv@yandex.ru),

Красильщиков Анатолий Владимирович ( krasilschikov@inbox.ru ), Мищенко Вячеслав Иванович (vyacheslav-mischenko@mail.ru ).

Журнал «Современная наука: актуальные проблемы теории и практики»
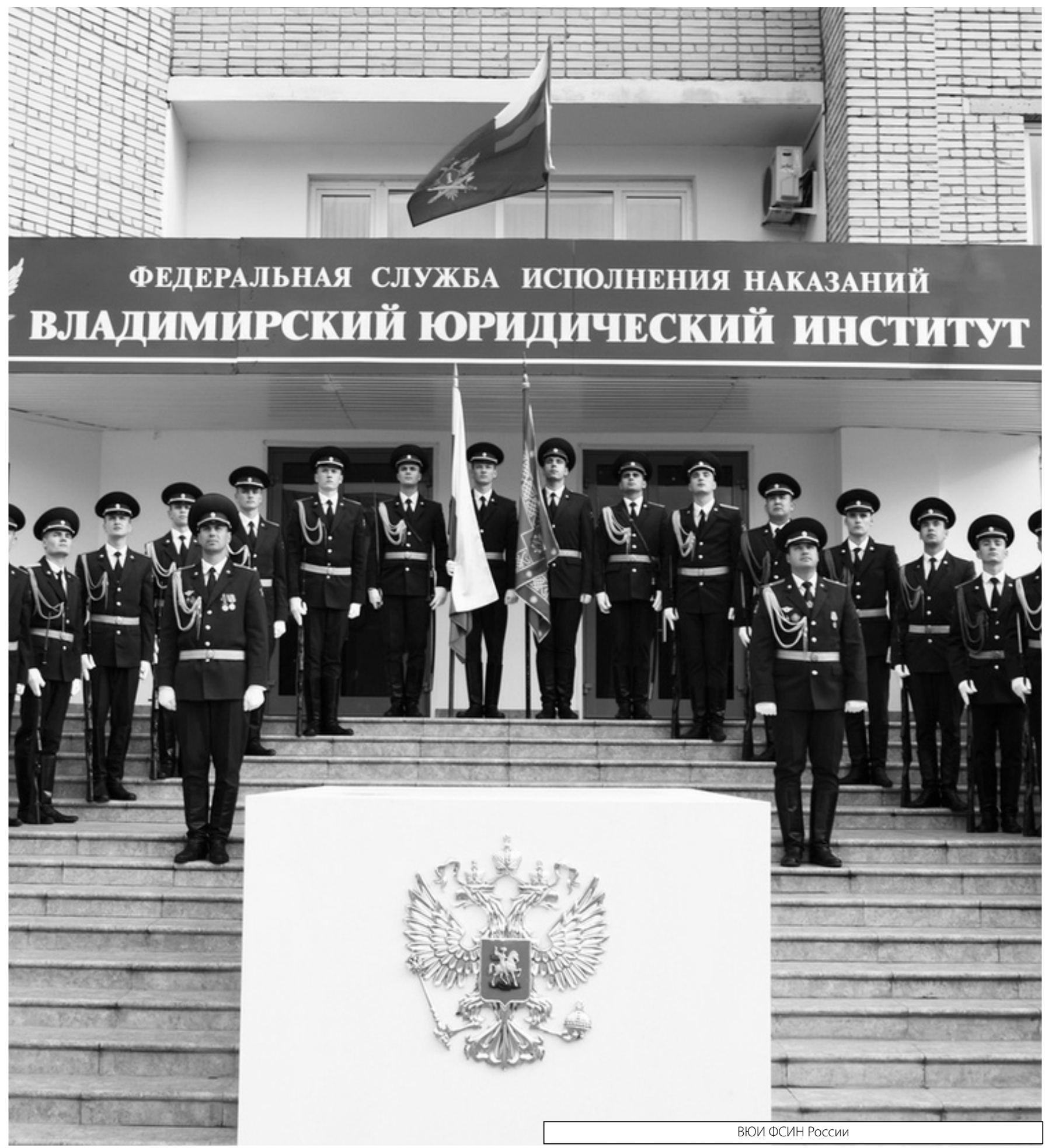